\title{
Judicial Enforcement of Environmental Democracy: a Critical Analysis of Case Law on Access to Environmental Information in the European Union
}

\author{
Marjan PEETERS * \\ Professor, Wuhan University, Wuhan, China \& Professor, Maastricht \\ University, Maastricht, The Netherlands \\ marjan.peeters@maastrichtuniversity.nl
}

\begin{abstract}
Since the 1970s, the concept of environmental democracy, including the right to gain access to environmental information, has emerged as an important concept to promote and ensure public engagement in governmental environmental decision-making. While it is, generally, understood that environmental procedural rights deserve protection across the globe, it remains to be identified to what extent, in practice, the application of such rights differs across jurisdictions. Such differences may be caused by specific understandings of democracy and institutional characteristics. In light of this, this article analyses the case law of the Court of Justice of the European Union (CJEU) regarding the right of access to environmental information. It observes that the EU legislature has implemented the right of access to environmental information more ambitiously than required under the Aarhus Convention, particularly with regard to legislative information. Moreover, the CJEU has steered EU institutions, including the European Commission, towards even greater transparency. The judicial reasoning by the CJEU is principled and refers to general values regarding openness and transparency codified in primary EU law and in the EU Charter of Fundamental Rights. These judicial developments also highlight the importance of promoting discourse on the implications of a rigorous approach to the right of access to environmental
\end{abstract}

* The author wholeheartedly thanks Mathias Müller (Ph.D student at Maastricht University), the peer reviewers, and the editors for their valuable comments on the draft of this article. Further, this article builds on case notes published by the author in the Dutch journal of environmental law, Tijdschrift voor Milieu \& Recht. 
information, including the question of whether enabling wider public engagement necessarily leads to better decision-making. Finally, the article promotes the need for comparative research on how the right to gain access to environmental information is developing across the world.

\section{Keywords}

Aarhus Convention - access to environmental information - effective and efficient decision-making - environmental democracy - EU law - EU Charter of Fundamental Rights - judicial enforcement - comparative research

\section{Introduction}

Since the 1970s, the concept of environmental democracy has emerged as an important concept to promote and ensure public engagement in governmental environmental decision-making. ${ }^{1}$ In legal terms, three procedural environmental rights have been instrumental to the practical application of environmental democracy, namely, the rights of access to information, public participation and access to justice in environmental decision-making. Underlying the concept of environmental democracy is the idea 'that an informed and legally empowered citizen is the most important aspect of environmental democratisation'. ${ }^{2}$ At the international level, these three rights were codified expressly for the first time in the 1998 Convention on Access to Information, Public Participation in

1 The question of what constitutes environmental democracy has been the subject of extensive commentary in the literature extending back several decades. While these discussions are outside the scope of this article, see eg, Joshua C GELLERS and Chris JEFFORDS, 'Toward Environmental Democracy? Procedural Environmental Rights and Environmental Justice' (2018) 18(1) Global Environmental Politics 99; Gyula BÁNDI, 'Introduction to the Concept of 'Environmental Democracy' in Gyula BÁNDI (ed), Environmental Democracy and Law (Europa Law Publishing, 2014); Giulia PAROLA, Environmental Democracy at the Global Level: Rights and Duties for a New Citizenship (Veritas Publishing, 2013); Marianne DELLIGNER, 'Ten Years of the Aarhus Convention: How Procedural Democracy Is Paving the Way for Substantive Change in National and International Environmental Law' (2012) 23 Colorado Journal of International Environmental Law and Policy 309; Jonas EBBESSON, 'A Modest Contribution to Environmental Democracy and Justice in Transboundary Contexts: The Combined Impact of the Espoo Convention and Aarhus Convention' (2011) 20(3) Review of European Community \& International Environmental Law 248; Michael MASON, Environmental Democracy: A Contextual Approach (1st edn 1999, Routledge 2012).

2 PAROLA (n 1$) 5$ o. 
Decision-making and Access to Justice in Environmental Matters (the Aarhus Convention $)^{3}$ and, more recently, in the 2018 Regional Agreement on Access to Information, Public Participation and Justice in Environmental Matters in Latin America and the Caribbean (the Escazú Agreement). ${ }^{4}$

While all three environmental rights make important contributions to environmental democracy, the right of access to information is fundamental to enabling citizens to effectively use the other two rights, such as participation in governmental decision-making. Moreover, it counters the existence of information asymmetry between decision makers and those affected by their decisions, including individuals, special interest groups and citizens more generally. Accordingly, this article's primary focus is on the right of access to information as provided by the Aarhus Convention and the important role of courts in enforcing this right. According to Article 9 of the Aarhus Convention, its parties must ensure that any member of the public, including Environmental Non-Governmental Organisations (ENGOS), has access to a court in situations where a request for information is refused. ${ }^{5}$ For the European Union, being a party to the Aarhus Convention together with all its Member States, the Court of Justice of the European Union (CJEU) has the power to decide whether a request to gain access to environmental information was lawfully refused by public authorities at EU level, such as the European Commission. Refusals to

3 Convention on Access to Information, Public Participation in Decision-Making and Access to Justice in Environmental Matters (adopted 25 June 1998, entered into force 30 October 2001) 2161 UNTS 447. The high number of ratifications to the Aarhus Convention is seen as a success, as discussed in Elena FASOLI, 'The UNECE Convention on Access to Information, Public Participation in Decision-Making and Access to Justice in Environmental Matters', in Malgosia FITZMAURICE, Attila TANZI, and Angeliki PAPANTONIOU (eds), Multilateral Environmental Treaties (Edward Elgar Encyclopaedia of Environmental Law, 2017) Ch 38, 433.

4 Regional Agreement on Access to Information, Public Participation and Justice in Environmental Matters in Latin America and the Caribbean (adopted 4 March 2018 by 24 nations), opened for signature from 27 September 2018 to 26 September 2020. The Escazú Agreement will enter into force after ratification by eleven countries; nine have ratified to date; see <https://www.cepal.org/en/escazuagreement>. See for an overview: Lalanath DE SILVA, 'Escazú Agreement 2018: A Landmark for the LAC Region' (2018) Chinese Journal of Environmental Law 2 93-98 (also explaining that the agreement emerged from a civil society initiative).

5 Aarhus Convention, art 9(1): 'Each Party shall, within the framework of its national legislation, ensure that any person who considers that his or her request for information under article 4 has been ignored, wrongfully refused, whether in part or in full, inadequately answered, or otherwise not dealt with in accordance with the provisions of that article, has access to a review procedure before a court of law or another independent and impartial body established by law.' 
provide environmental information have led to a number of court decisions from which some important legal lessons can be learned.

Insight into the extent to which access to environmental information can be enforced through the courts is not only useful from an EU perspective but it also provides a means to compare the right to access environmental information across jurisdictions in other regions. While it can be generally understood that, given their universal nature, human rights deserve protection across the globe, it remains to be identified how, in practical legal terms, the application of the right to access environmental information differs from one jurisdiction to another. Any such difference may be caused by the specific culture, the specific understanding of democracy and institutional characteristics in a particular jurisdiction. ${ }^{6}$ Of course, in this respect, a careful comparison is necessary. For instance, the provision of exceptions to the obligation to disclose environmental information is regulated differently in the Escazú Agreement as compared to the Aarhus Convention. The former expects parties to provide specific grounds for refusal in their domestic legislation and offers a default approach in case a Party does not enact such a domestic legal regime. ${ }^{7}$ In contrast, article 4 of the Aarhus Convention prescribes grounds of refusal that have to be made applicable in the jurisdictions of the parties, while in the national legal frameworks a less strict regime, enabling more openness, can be provided. ${ }^{8}$ Differences in the legal frameworks for access to environmental information may lead to differences in the extent to which the public can enforce access to environmental information. However, this can only be confirmed by studying the case law.

The specific focus of this article is on the key decisions of the CJEU concerning the right to gain access to environmental information. The extent to which, and for what reasons, the Court has found that the EU Commission acted unlawfully in view of the obligation to provide access to environmental information on request of a member of the public will be examined. In various cases, the CJEU — functioning as the appeal body_disagreed with the judicial decision taken at first instance by the General Court of the EU. This

6 Gráinne DE BÚRCA, 'After the EU Charter of Fundamental Rights: the Court of Justice as a Human Rights Adjudicator?' (2013) 20(2) Maastricht Journal of European and Comparative Law 181-182. On how environmental procedural rights and particularly also the right to access information was understood in former UssR countries, see Tataniana R ZAHARCHENKO and Gretta GOLDENMAN, 'Accountability in Governance: The Challenge of Implementing the Aarhus Convention in Eastern Europe and Central Asia' (2004) 4 International Environmental Agreements: Politics, Law and Economics 229-251.

7 Escazú Agreement, articles Art 5(5) and 5(6). Discussed by DE SILVA (n 4) 97.

8 DE SILVA (n 4) 97. 
exemplifies the different appreciation that judicial adjudication can have with regard to interpreting and applying the right of any member of the public to access environmental information as enshrined in the Aarhus Convention and as implemented in EU law. ${ }^{9}$ In this vein, observations will be made on the clarity and detail of the judicial reasoning that urges the EU Commission to act more rigorously with respect to providing transparency to its decision-making.

In addressing these issues, Section 2 commences with an overview of international law developments regarding environmental procedural rights, followed by the incorporation in EU law of the Aarhus Convention's procedural right of access to environmental information concerning access to environmental information held by EU institutions. Section 2 concludes with a justification of the selection of case law made in this article.

In Section 3, the discussion turns to decisions of the CJEU that consider the right of access to environmental information. Consideration is given to the CJEU's legal reasoning in circumstances in which it has found that the EU Commission has acted unlawfully in view of its obligation to provide access to environmental information in response to a request from a member of the public. This discussion delves into core elements of the right of access to environmental information considered in the case law, specifically:

(i) The extent to which environmental information held by legislative institutions should be disclosed;

(ii) Specific interpretations of the grounds for refusing a request for environmental information that may be used by public authorities; and

(iii) What can constitute information relating to emissions into the environment.

Section 4 then provides a critical reflection on how the CJEU has adjudicated the appeals concerning the EU Commission's refusal to provide access to environmental information. This highlights the need for further reflection on how to preserve the efficiency and effectiveness of governmental decision-making, while at the same time ensuring transparent governance and access to environmental information. In addressing these matters, observations are made concerning the clarity and detail of the CJEU's judicial reasoning, especially where the Court urges the EU Commission to act more rigorously with respect to providing transparency in its environmental decision-making. Concluding remarks are set out in Section 5 , including on the need for comparative research on how the right to gain access to environmental information is developing across the world.

9 The implementation of the Aarhus Convention in EU law will be discussed in section 2. 


\subsection{Recognition of Environmental Procedural Rights in International Law}

According to WORKER and RATTÉ, environmental democracy embeds the 'idea that meaningful participation by the public is critical to ensuring that [environmental] decisions adequately and equitably address citizens' interests' ${ }^{10}$ In terms of practical implementation, 'environmental democracy involves three mutually reinforcing rights' that encompass the 'ability for people to freely access information on environmental quality and problems, to participate meaningfully in decision-making, and to seek enforcement of environmental laws or compensation for damages.'11 Several international treaties and other instruments have clearly recognised environmental democracy in these terms. Notably, Principle 10 of the 1992 Rio Declaration on Environment and Development ${ }^{12}$ provides that:

Environmental issues are best handled with the participation of all concerned citizens, at the relevant level. At the national level, each individual shall have appropriate access to information concerning the environment that is held by public authorities, including information on hazardous materials and activities in their communities, and the opportunity to participate in decision-making processes. States shall facilitate and encourage public awareness and participation by making information widely available. Effective access to judicial and administrative proceedings, including redress and remedy, shall be provided.

The Aarhus Convention expressly recognises the international community's endorsement of environmental democracy, as set out in Principle 10 of the Rio Declaration. As indicated in the introduction, the Aarhus Convention is based on three pillars, namely (i) access to environmental information; ${ }^{13}$ (ii) public participation in environmental decision, policy and law making; ${ }^{14}$

10 Jesse WORKER and Stephanie RATTÉ, 'What Does Environmental Democracy Look Like?' (World Resources Institute, 2014) <https://www.wri.org/blog/2014/o7/what-does -environmental-democracy-look>.

11 Ibid.

12 United Nations Conference on Environment and Development, 'Rio Declaration on Environment and Development', UN Doc A/CONF 151/26 (vol I); 31 ILM 874 (1992).

13 Aarhus Convention, arts 4 and 5 .

14 Ibid arts 6, 7 and 8. 
and (iii) access to justice. ${ }^{15}$ Another notable development is the establishment of the Environmental Democracy Index in 2015 (EDI 2015), a platform that measures the implementation of environmental procedural rights across 70 countries, using an internationally recognized set of guidelines developed through the United Nations Environment Programme. ${ }^{16}$ In 2018, twenty years after the Aarhus Convention was introduced, the second regional agreement regarding environmental procedural rights was established, the Escazú Convention. ${ }^{17}$ Like its European counterpart, this provides express recognition to the three key environmental rights mentioned above. ${ }^{18}$

Regarding the right of access to environmental information, the results of the EDI 2015 pointed out that even though ' $93 \%$ of 70 assessed countries have established the right to environmental information', only just over half of these States 'have strong protections to ensure that citizens enjoy affordable and convenient access' to this information. ${ }^{19}$ Accordingly, this article's focus is on the first pillar of the three environmental procedural rights - the right of access to information - and the challenges preventing its implementation. Legal recognition of this right in the EU and an overview of the relevant legal framework governing its application are discussed next.

\subsection{The EU Legal Framework on Access to Environmental Information}

Before delving into an analysis of the court decisions, a concise overview will be given of the applicable legal framework that establishes the right to gain access to environmental information in EU law. ${ }^{20}$ This legal framework consists of (a) the provisions for access to information that apply across the EU, and, (b) specific provisions with regard to environmental information.

First, the right to gain access to documents is straightforwardly provided in the Charter on Fundamental Rights of the European Union (the Charter). ${ }^{21}$ Article 42 of the Charter reads: 'Any citizen of the Union, and any natural or

15 Ibid art 9 .

16 World Resources Institute, 'Environmental Democracy Index: A right to know, a right to be heard, a right to access justice' <https://www.wri.org/our-work/project/environmental -democracy-index $>$.

17 See above (n 4$)$.

18 As discussed by DE SILVA ( $\mathrm{n} 4)$.

19 The Equality \& Democracy Project, 'The Need for Environmental Democracy' (YaleNUS College, December 2017) <https://equalitydemocracy.commons.yale-nus.edu.sg/ 2017/12/o7/the-need-for-environmental-democracy/>.

20 The focus of this article is on the passive form, meaning that members of the public can ask for environmental information held by the government—and not on the active form, which is on the dissemination of information without a request.

21 Charter of Fundamental Rights of the European Union [2012] OJ C 326/391. 
legal person residing or having its registered office in a Member State, has a right of access to European Parliament, Council and Commission documents. ${ }^{22}$ The right is textually limited to 'documents', while in the specific EU legislation on access to environmental information discussed below, information includes 'any information in written, visual, aural, electronic or any other material form.'23

Furthermore, in EU primary law, the Treaty on European Union (TEU $)^{24}$ and the Treaty on the Functioning of the European Union (TFEU $)^{25}$ provide several provisions on transparency; article 1 TEU already states that decisions need to be taken 'as openly as possible and as closely as possible to the citizen'. Article 15 TFEU provides the 'right of access to documents of the Union's institutions, bodies, offices and agencies, whatever their medium'. The right provided by Article 15 T FEU is subjected to more precise principles and conditions set forth in EU Regulation 1049/2001, on general access to information of the EU (the Access to Information Regulation). ${ }^{26}$ That Regulation, in article 1, provides a legal framework 'to ensure the widest possible access to documents' and also to ensure 'the easiest possible exercise of this right'. Specifically for 'environmental information', the Access to Information Regulation is complemented by Regulation 1367/2006 (the Aarhus Regulation) which implements the access to environmental information provision of the Aarhus Convention with regard to EU institutions and bodies. ${ }^{27}$ According to EU law, international agreements concluded by the EU, such as the Aarhus Convention, are binding upon the institutions of the Union and consequently prevail over the acts laid down by those institutions. This implies that a decision adopted by the EU may be assessed by the CJEU on its compatibility with the Aarhus Convention,

22 Articles 42, 43 (concerning the Ombudsman) and 44 (Right of Petition) of the Charter explicitly specify rights not only for natural persons but also for 'legal persons'.

23 This is provided in art 2(1)(d) of Regulation (EC) No 1367/2006 of the European Parliament and of the Council of 6 September 2006 on the application of the provisions of the Aarhus Convention on Access to Information, Public Participation in Decision-making and Access to Justice in Environmental Matters to Community institutions and bodies [2006] OJ L 264/13 (henceforth the 'Aarhus Regulation').

24 Consolidated Version of the Treaty on European Union [2008] OJ C 115/13.

25 Consolidated version of the Treaty on the Functioning of the European Union [2008] OJ $\mathrm{C}_{32} 6 / 47$.

26 Regulation (EC) No 1049/2001 of the European Parliament and of the Council of 3o May 2001 regarding public access to European Parliament, Council and Commission documents [2001] OJ L 145/43.

Aarhus Regulation (n 27). 
if the treaty provisions can be qualified as 'unconditional and sufficiently precise.'. 28

With regard to transparency to be provided by EU Member States, EU law contains a separate legal framework. Directive 2003/4/EC, which differs to some extent from the legal framework that is applicable to the EU institutions and bodies, obliges Member States to provide for the right of access to environmental information in their national legislation. ${ }^{29}$ While this article concentrates on adjudication regarding requests for environmental information submitted to EU institutions and bodies, the particular CJEU decisions answering preliminary references submitted by national courts that are called on to adjudicate requests for environmental information addressed to national authorities are also discussed.

\subsection{Focus on Selected Key Cases of the cJEU}

With specific regard to procedural environmental rights, the CJEU has been called upon at various times to adjudicate appeals against decisions by the General Court concerning requests for access to environmental information held by EU institutions and bodies, particularly where this concerns the European Commission. ${ }^{30}$ ENGOs, which have been particularly willing to scrutinize and improve environmental decision-making at EU level, have spurred this case law. While establishing standing in these matters is relatively easy, ${ }^{31}$ several ENGOs have the capacity-in terms of human resources and finance- - to address the courts if access to information is refused. Nonetheless, incidentally, private actors such as those from industry also make use of the right of access to environmental information, as discussed in section 3.2. ${ }^{32}$

28 See, for instance, C-612/13 ClientEarth v European Commission [2015] ECLI:EU:C:2015:486, para $33-35$.

29 Directive 2003/4/EC of the European Parliament and of the Council of 28 January 2003 on public access to environmental information and repealing Council Directive 9o/313/ EEC [2003] OJ L 41/26 (the 'Access to Environmental Information Directive'). While the Aarhus Regulation and the Access to Environmental Information Directive implement the same provision of the Aarhus Convention (particularly the Convention's article 4), the two secondary legislative instruments are not exactly the same. The question whether legislative institutions are covered by the access to environmental information regulatory framework is discussed in section 3.1.

3o More generally, DE BÚRCA argued in 2013 that the CJEU has little experience of adjudicating human rights issues in any depth': DE BÚRCA (n 6) 170.

31 Article 2 of the Aarhus Regulation provides that 'applicant' means 'any natural or legal person requesting environmental information'. Furthermore, article 8 of the Access to Information Regulation provides the right of these applicants to address the Court.

32 See Case C-6o/15 P, Saint-Gobain Glass Deutschland v European Commission [2017] ECLI:EU:C:2017:540. 
The selection of cases in this article is motivated firstly by instances of disagreement between the CJEU and the General Court on the lawfulness of a decision to reject a request for information, and secondly whether the adjudication deals with a core element of the legal framework that provides the right of access to environmental information. In this sense, the article reveals how, according to the judgments, the EU Commission has to provide more transparency by disclosing environmental information when requested to do so.

\section{Enforcing Environmental Democracy in the EU: Case Law of the CJEU}

\section{1}

\section{Environmental Information Held by EU Legislative Bodies}

\subsubsection{The Issue}

While the Aarhus Convention excludes legislative bodies from its scope, the EU has explicitly subjected its legislative institutions to access to information provisions. ${ }^{33}$ Alongside several provisions directing institutions acting in a legislative capacity to provide information on their own motion, ${ }^{34}$ any member of the public can request $\mathrm{EU}$ institutions acting in a legislative capacity to provide access to previously undisclosed information. This follows from the Access to Information Regulation, which aims to give 'the fullest possible effect to the right of public access to documents'. ${ }^{35}$ As a general rule, 'documents drawn up or received in the course of a legislative procedure shall be

33 Access to Information Regulation, article 2(4). The Aarhus Convention seems to contain a textual inconsistency in this respect: Article 2(2) of the Aarhus Convention stipulates that the definition of 'public authority' does not include bodies or institutions acting in a 'legislative capacity' (article 4(1) of the Aarhus Convention limits the provision regarding the right to access environmental information to 'public authorities') while the definition of 'environmental information' includes 'legislation', see article 2(3)(b) of the Aarhus Convention. Hence, while, on the one hand, the Aarhus Convention excludes the legislator from the definition of 'public authority', the definition of environmental information does, on the other hand, include 'legislation'. Furthermore, the preamble to the Aarhus Convention recognizes 'the desirability of transparency in all branches of government' and invites 'legislative bodies to implement the principles of this Convention in their proceedings'.

34 The TFEU obliges the European Parliament to meet in public, as 'shall the Council when considering and voting on a draft legislative act.' Such a provision does not apply with regard to the Commission. For a critical perspective on the often-confidential negotiations for the adoption of secondary legislation, see Kieran St C BRADLEY, 'Legislating in the European Union' in Catherine BARNARD and Steve PEERS (eds) European Union Law (Oup 2014) 119-120.

Access to Information Regulation, recital 4. 
made directly accessible. ${ }^{36}$ Furthermore, the Aarhus Regulation explicitly provides that $\mathrm{EU}$ institutions or bodies acting in a legislative capacity are covered by the provision regulating access to environmental information. ${ }^{37}$ However, a refusal by the European Commission to disclose documents developed during its considerations as whether to initiate a procedure for having a law adopted by the Council of the European Union ${ }^{38}$ and the European Parliament led to a decision by the Grand Chamber of the CJEU in a case started by the ENGo ClientEarth. ${ }^{39}$ The considerations by the Commission concentrated on proposing new measures for two key issues in the field of EU environmental law that, for some time already, could not be put into binding EU legislation because of lack of political support. The first measure concerned the adoption of requirements for inspection and surveillance of EU environmental legislation by Member States. The second measure that the Commission considered was whether to propose an EU law regulating access to national courts in environmental matters. For both issues, impact statements were prepared, together with draft opinions from the Impact Assessment Board. ${ }^{40}$ The Commission refused to provide access to these documents while it was deliberating howand more specifically, in what form, to move forward (such as by means of a non-binding communication, or an initiative for a legislative proposal to the European Parliament and the Council). The Grand Chamber reached a principled decision with significant consequences for the information practice of the European Commission. More specifically, this resulted in a prohibition

36 Access to Information Regulation, article 2(4).

37 Aarhus Regulation, article 2(1)(c).

38 The Council is, together with the European Parliament, the main decision-making body of the EU, and consists of government ministers from each EU country. A different institution of the EU is the European Council, which consists of EU leaders, and sets the broad direction of EU policy making.

Case C-57/16, ClientEarth v European Commission [2018] ECLI:EU:C:2018:66o. The CJEU sits as a Grand Chamber when a Member State or an institution which is a party to the proceedings so requests, as well as in particularly complex or important cases. A Grand Chamber of the European Court normally consists of 15 judges; see <https://curia.europa .eu/jcms/jcms/Jo2_7024/en/\#composition>.

40 Concerning the access to justice issue, the requested documents concerned draft impact statements; see the judgment (n 39) para 10. Impact assessments form part of the European Commission's policy for achieving better regulation; for more information see 'The need for impact assessments' <https:/ec.europa.eu/info/law/law-making-process/ planning-and-proposing-law/impact-assessments_en>. According to this policy, impact assessments will be carried out to examine 'whether there is a need for EU action and analyse the possible impacts of available solutions'. The 'Impact Assessment Board' has been replaced by the Regulatory Scrutiny Board, see <https://ec.europa.eu/info/law/ law-making-process/regulatory-scrutiny-board_en>. 
on the Commission using a general assumption that documents used during the deliberations on whether or not to initiate a legislative proposal do not have to be released. Instead, the Commission is forced to provide specific argumentation, based on the grounds of refusal listed in the Access to Information Regulation and the Aarhus Regulation, as to why it would be legitimate not to disclose such documents. Given the strong emphasis by the Grand Chamber of the CJEU on democracy and its implied necessity that citizens must be able to control the decision-making processes, such justification may be difficult to find. The case thus constituted a major win for ClientEarth, which was supported in this legal contest by two Member States generally known for their positive stance concerning transparency (Finland and Sweden). ${ }^{41}$

\subsubsection{Main Judicial Argumentation: the Democratic Rights of Citizens} The European Commission argued that confidentiality should be maintained during its deliberations in order to be free from external pressures. Indeed, the Access to Information Regulation enables the refusal of a document to be disclosed relating to a matter where the decision has not yet been taken, if disclosure would seriously undermine the decision-making process. ${ }^{42} \mathrm{~A}$ refusal to disclose information may not be based on this ground in a situation where there is an 'overriding public interest in disclosure'. ${ }^{43}$ According to the Commission, 'disclosure would restrict its room for manoeuvre, reduce its ability to reach a compromise, and might create external pressures which could hinder those delicate processes, during which an atmosphere of trust ought to prevail. ${ }^{44}$ According to the Court of first instance (the so-called General Court), the claim by the Commission to be in need of confidential deliberations was supported by Article $17 \mathrm{TEU}$, stating in its paragraph (3) that the Commission needs to function 'in a fully independent manner and exclusively in the general interest' and that the members of the Commission should 'neither seek nor take instructions' from other authorities. ${ }^{45}$ Additionally, the Commission argued that consultation had been carried out before the Commission began

41 Note also that the CJEU in ClientEarth ( $\mathrm{n} 39$ ) paras 55 and 56 decided that ClientEarth still had an interest in bringing the proceeding even though the Commission - by the time of the judicial deliberation - had disclosed all documents. If no judicial decision had been given on the matter, the ENGO could be confronted again with the general presumption of non-disclosure applied by the Commission. Access to Information Regulation, article 4(3).

43 Ibid.

44 ClientEarth (n 39) para 13.

45 Ibid, with the summary of the General Court's considerations regarding article 17 TEU in para 25 . 
to deliberate on how to move forward, ${ }^{46}$ and that after the deliberations, the documents would be disclosed 'upon the adoption of the legislative proposals'. ${ }^{47}$ The CJEU, in turn, focused on fundamental values enshrined in primary EU law, essentially guaranteeing transparency of EU decision-making. ${ }^{48}$ More specifically, it pointed to the first article of the TEU, calling for decisions to be taken 'as openly as possible', and article 42 of the Charter (both cited in section 2.2 above) ${ }^{49}$

The Court also provided a wide interpretation of what is to be understood with 'documents adopted by the EU institutions when acting in their legislative capacity' and made this applicable to documents drawn up in the context of an impact assessment procedure (which in practice may or may not be followed by a proposal for a secondary law). ${ }^{50}$ Then, although the CJEU recognized that the Commission 'must be able to enjoy a space for deliberation in order to be able to decide as to the policy choices to be made and the potential proposals to be submitted, ${ }^{51}$ this does not mean that the Commission may, generally keep legislative documents, including impact assessments, confidential since that would be detrimental to the democratic rights of EU citizens. ${ }^{52}$ More precisely, the Court stated that it would limit 'the expression by the public or the interested parties of their views on the choices made and the policy

$46 \quad$ Ibid para 18

47 Ibid para 16. In a situation where no legislative proposals were adopted, the question is whether the requested documents would be released.

48 Ibid paras $73^{-81}$.

49 The CJEU also clarified the term 'legislative document' in line with article 12 of the Access to Information Regulation: 'not only acts adopted by the EU legislature, but also, more generally, documents drawn up or received in the course of procedures for the adoption of acts which are legally binding in or for the Member States, fall to be described as 'legislative documents": ClientEarth (n 40) para 85.

50 Ibid paras 95 and para 101. See Aarhus Regulation, article 2(1)(c); Also, see an earlier decision by the Grand Chamber outside the environmental field: Case C-213/15 P, Commission $v$ Patrick Breyer [2017] ECLI:EU:C:2017:563, para 51 and para 2: 'That broad interpretation of the principle of access to documents of the EU institutions is, moreover, borne out by Article 15(1) TFEU, which provides that the institutions, bodies, offices and agencies of the EU are to conduct their work as openly as possible, that principle of openness also being expressed in the second paragraph of Article 1 TEU and Article 298 TFEU, and by the enshrining of the right of access to documents in Article 42 of the Charter of Fundamental Rights of the European Union.'

$51 \quad$ ClientEarth (n 39) para 109.

$5^{2}$ In its earlier case law, the CJEU accepted that for certain specific categories of decisions, the authority may work with a general presumption of confidentiality: ClientEarth ( $\mathrm{n}$ 39) para 51. This was also decided in another case with regard to access to information initiated by ClientEarth: C-612/13 (see n 29, ClientEarth, on the accessibility of documents in an infringement procedure). 
options envisaged by the Commission in the context of its initiatives, in particular its legislative initiatives in respect of environmental matters, before that institution has made a decision regarding the planned initiative. ${ }^{53}$ Carrying out such activities 'is an integral part of the exercise by EU citizens of their democratic rights. ${ }^{54}$ It also held that the provisional nature of the preparatory documents was no reason to work with a general presumption of the need for confidentiality. In essence, the CJEU expects the Commission to provide convincing argumentation as to why documents should not be disclosed. ${ }^{55}$ The CJEU henceforth set aside the judgment of the General Court and annulled the decisions of the Commission in which disclosure was refused. ${ }^{56}$

The positive stance of the CJEU with regard to transparency in preparatory legislative processes can also be identified in two earlier cases that relate to legal conflicts on access to environmental information at Member State level. These two decisions were laid down with regard to refusals by German authorities to provide access to legislative documents. ${ }^{57}$ The EU secondary legislation implementing the Aarhus Convention shows a remarkable difference between the obligations directed at EU level and the obligations directed at Member State level. For the latter, the Member State may decide whether to expand the applicability of the access to information provisions to legislative bodies, while at EU level, as is shown above, the provisions concerning access to information are explicitly addressed to the EU institutions acting in a legislative capacity. ${ }^{58}$ The pro-transparency reasoning employed by the CJEU is particularly apparent in its decision regarding the refusal of a German ministry to provide access to documents which were part of the legislative process of the Federal German

\footnotetext{
53 ClientEarth (n 39) para 108.

54 Ibid.

55 Ibid para 111. The risk that the decision-making process would be seriously undermined 'depends on factors such as the state of completion of the document in question and the precise stage of the decision-making process in question at the time when access to that document is refused, the specific context in which that process takes place, and the issues still to be discussed internally by the institution concerned.'

$5^{6}$ With this adjudication, the CJEU reaffirms earlier case law that exceptions to disclosure must be interpreted and applied strictly: see, for instance, Saint-Gobain case ( $\mathrm{n} 32)$ further discussed in section 3.2.

57 Case C-204/o9, Flachglas Torgau v Bundesrepublik Deutschland [2012] ECLI:EU:C:2012:71 and Case C-515/11 Deutsche Umwelthilfe eVc v Bundesrepublik Deutschland [2013] ECLI:EU:C:2013:523, discussed by Marjan PEETERS and Sandra NÓBREGA 'Climate Change-related Aarhus Conflicts: How Successful are Procedural Rights in EU Climate Law?' (2014) 23(3) Review of European Community and International Environmental Law 354-366.

$5^{8}$ Access to Environmental Information Directive (n 29) article 2(2).
} 
legislator: when the legislative process has ended, the documents should in principle be disclosed. ${ }^{59}$

\subsection{Undermining the Decision-Making Process as a Ground for Refusal 3.2.1 The Issue}

Article 4 of the Aarhus Convention provides several options for governments to refuse a request for environmental information. The Access to Information Regulation, together with the Aarhus Regulation, regulate such options for EU authorities. ${ }^{60}$ Given the variety of options for refusal, different cases may come up in which the specific interpretation and application of a particular ground of refusal is contested. In addition to obtaining a detailed understanding of this specific case law, some important general insights can be gained, such as the strictness with which the grounds for refusal must be interpreted. Such insight is provided by the CJEU in an appeal by a German company against a decision from the General Court, which found a refusal to disclose environmental information by the Commission lawful. However, contrary to the General Court, the CJEU found that the refusal to disclose was unlawful. ${ }^{61} \mathrm{In}$ this case, the request for information had been submitted by a company that wanted the European Commission to disclose a document that it had received from the German government. This document included information with regard to the implementation of the EU greenhouse gas Emissions Trading System (the EU ETS) with specific information regarding several installations operated by the company. ${ }^{62}$ The European Commission provided only partial access and considered that full disclosure would seriously undermine the institution's internal decision-making process. ${ }^{63}$ This ground for refusal

59 More precisely, the court decided: 'the option given to Member States ... of not regarding bodies or institutions acting in a legislative capacity as public authorities can no longer be exercised where the legislative process in question has ended': Flachglas Torgau (n 57) para 58 . Of course, it may be the case that the public authority may still find (another) applicable ground for refusal.

6o Article 4 of the Access to Information Regulation read in conjunction with Article 6 of the Aarhus Regulation.

$61 \quad$ Saint-Gobain (n 32).

62 The industry (Saint-Gobain) requested an Excel document with a list communicated by the Federal Republic of Germany to the Commission with the intention of implementing the free allocation of emission allowances to the extent that that document contained information relating to certain installations of Saint-Gobain, see Saint-Gobain (n 32) para 1 and 17 .

63 Article $4(6)$ of the Access to Information Regulation provides: '[i]f only parts of the requested document are covered by any of the exceptions, the remaining parts of the document shall be released. The Commission had to communicate with Germany as to whether the requested information could be released, see Saint-Gobain (n 32) para 26. 
was provided in an obligatory way: according to article 4(3) of the Access to Information Regulation the information '... shall be refused if disclosure of the document would seriously undermine the institution's decision-making process ...' (emphasis added). ${ }^{64}$ However, according to the same article, this ground cannot be used if there is 'an overriding public interest in disclosure'. According to article 6, para 1, second sentence, of the Aarhus Regulation, the ground of refusal just mentioned 'shall be interpreted in a restrictive way, taking into account the public interest served by disclosure and whether the information requested relates to emissions into the environment'. The CJEU, however, did not have to interpret this specific environmental provision of the Aarhus Regulation, since it had formed the opinion that a restrictive interpretation is needed of the general criterion provided in the Access to Information Regulation, namely that the decision-making process will be seriously undermined. ${ }^{65}$ Significantly, Saint-Gobain, the corporation that brought the appeal against the refusal, referred to the objectives of the Aarhus Convention, namely for the Parties to guarantee the transparency of decision-making by public authorities as well as public participation in decision-making in the field of the environment. ${ }^{66}$ Hence, this case is an example of a situation where it was not an individual or an ENGO that was attempting to make use of the Aarhus Convention, but an economic enterprise. In the view of the applicant, the ground of the judgment under appeal, according to which it must be ensured that administrative procedures are able to take place in an atmosphere of total serenity and that they are protected from external pressure, cannot be reconciled with that objective. ${ }^{67}$ The CJEU accepted this argument and, consequently, the judgment of the General Court was set aside and the decision by the Commission to keep information confidential was annulled. Most peculiarly, this confirmed a victory for a polluting industry using the 'Aarhus right' to request environmental information regarding governmental decision-making concerning its own installations.

3.2.2 Main Judicial Argumentation: No General Presumption of the Need for Confidentiality

The Commission argued in a comparable way in the case regarding the request from ClientEarth concerning impact assessment documents during the prelegislative process, discussed in section 3.1. The Commission feared a serious

64 In this sense, article 4(3)(c) of the Access to Information Regulation is more restrictive concerning openness than the Aarhus Convention, which does not have such a provision.

65 Saint-Gobain (n 32 ) para 83.

66 Saint-Gobain (n 32$)$ para 40.

67 Opinion of Advocate General SZPUNAR in Case C 6o/15 P, Saint-Gobain Glass Deutschland GmbH v European Commission [2016] ECLI:EU:C:2016:778, para 25. 
undermining of its decision-making process with regard to the free allocation of tradable greenhouse gas allowances. This decision-making concerned many greenhouse gas emitting industries in the European Union. According to the Commission, full disclosure of the collected information concerning all these installations before the adoption of the decision 'would permit the public, and in particular the undertakings concerned, to raise questions or make criticisms in respect of the information communicated by the Member States, which would be likely to interfere with the decision-making process. Those interferences would, in turn, be likely seriously to delay the decision-making process and to prejudice the dialogue between the Commission and the Member States. ${ }^{68}$

In these cases, the CJEU has been engaging in a specific and new interpretation of the term 'decision-making process' that lacks a definition in the applicable regulations. The Court opined that 'the concept of "decisionmaking process" ... must be construed as relating to decision-making, without covering the entire administrative procedure which led to the decision.'69 Hence, the Court applied a restrictive interpretation that limits the possibility of using this ground of refusal. ${ }^{70}$ More particularly, the Court also considered that 'the mere reference to a risk of negative repercussions linked to access to internal documents and the possibility that interested parties may influence the procedure do not suffice to prove that disclosure of those documents would seriously undermine the decision-making process of the institution concerned. ${ }^{71}$ In this respect, it may be wondered whether, in the process of the decision-making, the authorities provided any opportunity for consultation with interested parties, particularly the industries, especially given the fact that the decision affects their specific position. ${ }^{72}$ In other words, if the Commission feared external pressure on the decision-making process, it could be an indication that it took a reluctant approach towards consultation

68 Saint-Gobain (n 32) para 25. The delay in decision-making could negatively impact the effective or timely operation of one of the core instruments of the EU for combating climate change, the emissions trading instrument, particularly in relation to its trading period to be commenced in 2013. The request for information was sent on 3 July 2012, less than 6 months before the trading period would begin (para 17 of the judgment).

69 Saint-Gobain (n 32 ) para 76.

70 Ibid para 78 . See also para 77 and $79-85$ for the motivations of the Court.

71 Ibid para 83 .

72 For, instance, the court held that, 'Member States are to calculate the provisional number of free emission allowances allocated from 2013 onwards to each incumbent installation on their territory on the basis of the reference values calculated by the European Commission' and that 'the results of those calculations are to be entered in the list of installations covered by Directive 2003/87 in the territory of each Member State, which is sent to the Commission by each State for verification': ibid para 16. 
or public participation to the decision-making for the free allocation of the allowances. ${ }^{73}$ However, with regard to this external pressure, the Court considered that according to the Aarhus Regulation there is no requirement 'to examine or respond to public reactions following the disclosure of documents containing environmental information relating to an administrative procedure in progress and divulging internal discussions. ${ }^{74}$ It may be true that, as such, the disclosure of information did not require the Commission to conduct a public participation procedure. However, it may be that, for instance, according the Aarhus Convention, public participation should be applied by the Commission before adopting a decision. ${ }^{75}$ No claim has yet been submitted to the CJEU on this public participation issue.

In summary, the Saint-Gobain case shows a large difference in the appreciation by, on the one hand, the Court of first instance, and, on the other hand, the appeal court of the need to protect the decision-making process from outside influences. ${ }^{76}$ Since this was also considered by the Grand Chamber in the ClientEarth case discussed in section 3.1, it has become quite clear that the fear of external pressure cannot be used to justify a general presumption of confidentiality. ${ }^{77}$

\section{3 'Emissions into the Environment' as a Restriction to Refusal \\ 3.3.1 The Issue}

While the Access to Information Regulation lists several reasons that governments can use to refuse disclosure of information, the Aarhus Regulation limits this possibility specifically for environmental information: 'an overriding public interest ${ }^{78}$ in disclosure 'shall be deemed to exist where the

73 I leave aside here an examination of the question whether and to what extent the Commission, or national authorities, have applied (or were required to apply) any public participation procedure including ENGOs, or, more restrictively, a consultation with the companies which would be directly influenced by the decision on the free allocation.

74 Saint-Gobain (n 32 ) para 84.

75 The public participation provisions from article 6, 7 and 8 of the Aarhus Convention are only partly implemented in the Aarhus Regulation (only for plans and programs, see article 9 of the Aarhus Regulation).

76 Saint-Gobain (n $3^{2}$ ) paras 68-75 (in which the Court considers the approach taken by the General Court, with which it disagrees).

77 The Grand Chamber in ClientEarth (n 39) frequently referred to the earlier Saint-Gobain decision, which is based on principled reasoning referring to article 1 TEU (SaintGobain ( $\mathrm{n}_{32}$ ) para 6o). The Grand Chamber in ClientEarth strengthened the principled reasoning by also referring to article 42 of the Charter.

78 The criterion 'overriding public interest' (which is textually more limiting to disclosure than 'the public interest') is stipulated several times in the Access to Information Regulation (article 4) with the aim of restricting the refusal of providing information. 
information requested relates to emissions into the environment. ${ }^{79}$ With this provision, the EU legislator established a further restriction to refusal of information compared to article 4 of the Aarhus Convention. In essence, it implies that if the information is about 'emissions into the environment', disclosure is obligatory. ${ }^{80}$ The $\mathrm{CJEU}$ had been called upon to adjudicate what is to be understood by 'emissions into the environment' related to a decision adopted by the European Commission to refuse information contained in documents about the substance glyphosate. This decision for refusal had been annulled by the court of first instance, the General Court. ${ }^{81}$ On the same day of this judgment, the CJEU handed down a decision on a prejudicial question from a national court in which it also provided an interpretation of what is to be understood by 'emissions into the environment'. 82 The term 'emissions' is not defined in the applicable Regulations, and a strict interpretation of this term-which was

79 This criterion, codified in article 6 of the Aarhus Regulation, applies to the possible grounds for refusal as stipulated in article 4(2), first and third indents, of the Access to Information Regulation, with the exception of investigations, in particular those concerning possible infringements of EU law. The first indent is about 'commercial interests of a natural or legal person, including intellectual property' and the third indent is about 'the purpose of inspections, investigations and audits'. See specifically for allowing confidentiality during infringement proceedings: joined cases C-514/11 P and C-6o5/11. The legislation is detailed and complicated-exceptions to exceptions are provided. The explanation in the main text concentrates on the core issue. For a precise understanding, close reading is required of article 6 of the Aarhus Regulation read in conjunction with article 4(2) of the Access to Information Regulation.

8o The Aarhus Convention requires that the grounds for refusal shall be interpreted in a restrictive way, 'taking into account the public interest served by disclosure and taking into account whether the information requested relates to emissions into the environment': article 4(4). However, in case of possible confidentiality of commercial and industrial information, information on 'emissions which is relevant for the protection of the environment' shall be disclosed according to article 4(4)d of the Aarhus Convention.

81 Case C-673/13 P, European Commission v Stichting Greenpeace Nederland and Pesticide Action Network Europe (PAN Europe) [2016] ECLI:EU:C:2016:889 (hereafter the Glyphosate appeal case); Case number of first instance is T-545/11, Stichting Greenpeace Nederland and Pesticide Action Network Europe (PAN Europe) v European Commission [2013] ECLI:EU:T:2013:523. For discussion, see Emilia korkeaO-Aho and Päivi LEINO, 'Who owns the information held by EU Agencies? Weed killers, commercially sensitive information and transparent and participatory governance' (2017) 54 Common Market Law Review 1059.

82 C-442/14, Bayer CropScience SA-NV and Stichting De Bijenstichting v College voor de toelating van gewasbeschermingsmiddelen en biociden [2016] ECLI:EU:C:2016:89o (hereafter Bijenstichting). This case originated from a request from a Dutch ENGO for disclosure of documents submitted by Bayer during procedures for the authorization of the placing of certain plant protection products and biocides on the Dutch (and, as a consequence, also on the European) market. 
pleaded for by the Commission - would narrow the obligatory disclosure of environmental information. ${ }^{83}$

The request concerned a draft assessment report issued by the Federal Republic of Germany, a complete list of all tests submitted by the applicants, and the full, complete and original test documents supplied by the applicants for the decision-making regarding glyphosate, insofar as this related to longterm toxicity tests, mutagenicity tests, carcinogenicity tests, neurotoxicity tests and reproduction studies. ${ }^{84}$

\subsubsection{Main Judicial Argumentation: Broad, but Not Unlimited, Interpretation ${ }^{85}$}

The CJEU provided a broad interpretation of what is to be understood by emissions into the environment, in view of the objective of the Aarhus Regulation, namely 'disclosing environmental information as widely as possible'. ${ }^{86}$ Moreover, the understanding of the term 'emission' 'varies according to the area in which it is to be applied.' ${ }^{87}$ The reasoning of the CJEU refers at various times to the Aarhus Convention, which is clearly seen as a reference point. ${ }^{88}$ Moreover, several cross-references are made to the other decision handed down the same day, where the Court gave the term 'emissions' a wider interpretation than explicitly foreseen by the Implementation Guide to the Aarhus Convention published on the UNECE website. ${ }^{89}$ The interpretation by the Court is based on the fact that the term 'emissions' does not only cover emissions from industrial installations, for instance, to water or air, but also 'the

83 The European Commission argued for a restrictive interpretation of the exception to the protection of confidential business information, meaning that information on emissions into the environment was to be deemed as an overriding public interest. The General Court considered that this would be the case if there was 'a 'sufficiently direct' link between the information concerned and emissions into the environment': Glyphosate appeal case (n 81) para 44. According to the Commission, this has no legal basis and the vague nature of that criterion raises serious problems in terms of legal certainty.

84 Glyphosate appeal case (n 81) para 17.

85 For earlier discussion see Marjan PEETERS, 'About Silent Objects and Barking Watchdogs: The role and accountability of Environmental NGOs' (2018) 24(3) European Public Law 46o-464.

86 Glyphosate appeal case (n 81) para 63, referring to the other decision on the same day (Bijenstichting (n 82)) para 73 .

$87 \quad$ Glyphosate appeal case (n 81) para 64.

88 ' $[\mathrm{T}]$ he Aarhus Convention, which must be taken into account in interpreting Regulation No $1367 / 2006$, since, as Article 1 thereof provides, the objective of that regulation is to contribute to the implementation of the obligations arising under that convention, by laying down rules to apply the provisions of that convention to EU institutions and bodies.' ibid para 61.

$89 \quad$ Bijenstichting (n 82) para 69. 
release into the environment of products or substances such as plant protection products or biocides and substances contained in those products, to the extent that that release is actual or foreseeable under normal or realistic conditions of use. ${ }^{90}$ Hence, the Court interpreted the definition in such a way that it also covers products or substances that are brought into the environment. Furthermore, 'information on emissions into the environment' is also given a broad meaning, including 'data concerning the medium to long-term consequences of those emissions on the environment, in particular information relating to residues in the environment following application of the product in question and studies on the measurement of the substance's drift during that application ..., whether the data comes from studies performed entirely or in part in the field, or from laboratory or translocation studies. ${ }^{91}$ The extensive interpretation can also be seen in the Court's consideration that (only) purely hypothetical emissions are not covered. ${ }^{92}$ With these wide interpretations, the Court gave a broad meaning to the right to access environmental information. Consequently, the CJEU in the appeal case confirmed the interpretation of the General Court that emissions into the environment are 'not limited to information concerning emissions emanating from certain industrial installations. ${ }^{93}$

The Commission's argument, that it is the duty of EU officials to respect the obligation of professional secrecy, in particular concerning information about (and, in this case, provided by) undertakings, as codified in article $339 \mathrm{TFEU}$, did not convince the CJEU. ${ }^{94}$ The Court stressed that the purpose of access to information is to promote more effective public participation, thereby increasing the accountability of decision-making. ${ }^{95}$ Furthermore, the Court stated that 'the public must have access to information enabling it to ascertain whether the emissions were correctly assessed and must be given the opportunity reasonably to understand how the environment could be affected by those emissions. 96

Despite these fundamental considerations implying a positive attitude towards disclosure of environmental argumentation, the Court took the view that the General Court went too far in its appreciation of the law and that

9o $\quad$ Ibid (see para 2).

91 However, the Court also provided a restriction, meaning that 'only relevant data which may be extracted from the source of information concerning emissions into the environment must be disclosed where it is possible to separate those data from the other information contained in that source, which is for the referring court to assess': ibid para 106.

92 Ibid para 80.

93 Glyphosate appeal case (n 81) para 70.

94 Ibid para 39.

95 Ibid para 8o.

96 Ibid. 
the concept of 'environmental information'97 should not be deprived of any meaning. Moreover, the Court argued that there should still be some possibility for the authorities to consider whether or not to disclose information based on the ground that such a refusal would have an adverse effect on the protection of the commercial interests. The wide application of the term 'emissions into the environment' would 'constitute a disproportionate interference with the protection of business secrecy' as is ensured by Article 339 TF EU. ${ }^{98}$ In other words, the CJEU corrected the General Court and allowed for some possibility for authorities to keep information confidential. The judgment of the General Court was therefore set aside, with the consequence that the case was sent back for further adjudication. In its subsequent decision, the General Court decided to dismiss the appeal, meaning that the ENGOs lost the case. ${ }^{99}$ The judicial argumentation for allowing the refusal of information merely rested on the fact that for a substance to be released to the environment, a subsequent national authorisation procedure will be decisive, and hence not the earlier procedure at EU level during which the ENGOs submitted their request for information. ${ }^{100}$

\section{Reflections on the CJEU's Approach to Enforcing Environmental Democracy}

\subsection{The Positive Role of the Court in Enforcing Access to Environmental Information}

Considering the case law discussed above, the CJEU has clearly contributed to more effective use of the right to access environmental information held by the European Commission. The argumentation used by the CJEU rests heavily on core democratic values enshrined not only in the Aarhus Convention but also in the TEU, the TFEU, the EU Charter of Fundamental Rights and the

\footnotetext{
97 Defined in Article 2(1)(d) of the Aarhus Regulation.

$98 \quad$ Glyphosate appeal case (n 81) para 81.

99 Case T-545/11 RENV, Stichting Greenpeace Nederland and PAN Europe v Commission [2018] ECLI:EU:T:2018:817. For a critical assessment of this General Court decision, holding it to be incorrect, see Ludwig KRÄMER, 'EU Emissions into the environment and confidentiality - Comment on General Court, case T-545/11 REN of 21 November 2018' (2018) 2/18 Environmental Law Network International 47.

100 Stichting Greenpeace (n 99) paras 88-90: 'the active substance 'glyphosate' is not intended to be released into the environment as such, but may be released only once integrated in a plant protection product subject to authorisation, the information contained in the document at issue cannot be covered by the concept of 'information relating to emissions into the environment' as defined by the Court of Justice in the judgment on appeal': ibid para 93 .
} 
preamble to the Access to Information Regulation. Through these cases, new, pro-access interpretations were given to elements of the EU legislative framework governing access to information, and, consequently, several decisions from the European Commission for the refusal of environmental information were found to be unlawful. More particularly, the CJEU urged that the refusal of a request for environmental information needs to be precisely and convincingly motivated and the fear of external pressure cannot be used to justify a general presumption of confidentiality with regard to the decision-making process by the Commission. ${ }^{101}$

With the adoption of the Aarhus Convention in 1998, the signatory parties, including the European Community, confirmed their intention to strengthen environmental democracy. For instance, the preamble to the Convention points to the aim 'to further the accountability of and transparency in decision-making and to strengthen public support for decisions on the environment'. ${ }^{102}$ In this respect, transparency in all branches of government is recognised as an important value. A comparable motivation is included in the preamble to the Aarhus Regulation: it stresses the importance of providing adequate environmental information and effective opportunities for public participation in environmental decision-making, thereby increasing accountability and transparency of decision-making and contributing to public awareness and support for the decisions taken'.103 Furthermore, the Access to Information Regulation states that '[o]penness enables citizens to participate more closely in the decision-making process and guarantees that the administration enjoys greater legitimacy.'104

However, in the Glyphosate case, the Commission's decision to refuse information was not found unlawful. Basically, given the stage of decision-making on authorisation, the release of the emissions into the environment was not

101 See section 3.1. On impact statements, see ClientEarth (n 39). On the prohibition to use a general presumption, see Saint-Gobain (n 32). For a contrasting decision, see C-514/11 P and C-605/11 P, LPN and Finland v Commission [2013] ECLI:EU:C:2013:738, paras 49-7o.

102 Preamble to the Aarhus Convention.

103 Aarhus Regulation, recital 2, pointing to the Sixth Community Environment Action Programme of 2002. The current legal basis for adopting action programmes is article 192(3) TFEU. Such an Action Programme has a guiding function, including for the European Commission. However, the Sixth Community Environment Action Programme does not have an explicit statement that adequate environmental information and effective opportunities for public participation in environmental decision-making increase 'support for the decisions taken'. See Decision No 1600/2002/EC of the European Parliament and of the Council of 22 July 2002, setting out the Sixth Community Environment Action Programme [2002] OJ L 242/1.

104 Access to Information Regulation, recital 2. 
yet to be expected. ${ }^{105}$ According to the judges, this implied that the broadly interpreted criterion of 'information on emissions in the environment' was not applicable. ${ }^{106}$ Nonetheless, the wide interpretation of this criterion by the CJEU will be relevant at a later stage when, in this complicated cascading authorisation procedure, approval for the substance will be requested at the national level-if, indeed, the ENGOs are willing and have the capacity to continue to strive towards disclosure of information by submitting repeated requests. With the broad interpretation given by the CJEU, an interpretation which is even broader than the one given in the Aarhus Implementation Guide, the accessibility of business information held by the government is, in principle, enlarged.

\subsection{Fundamental EU Values in Determining Access to Environmental Information}

The case law indicates that the adjudication by the CJEU requiring more transparency from the European Commission concerning environmental information is not exclusively based on the legal framework regulating access to environmental information. Further, primary EU law, including the Charter of Fundamental Rights is also relevant. In its considerations urging the Commission to provide transparency, the CJEU especially includes article 42 of the Charter. ${ }^{107}$ That article is formulated in a straightforward manner. It provides that ' $\mathrm{A}] \mathrm{A}$ ny citizen of the Union and any natural or legal person has a right of access to documents of the institutions, bodies, offices and agencies of the Union, whatever their medium'; that is, a right of access to European Parliament, Council and Commission documents. In secondary EU law, the Access to Information Regulation and the Aarhus Regulation provide possibilities for authorities to keep information confidential, unless there is an 'overriding public interest' in disclosure. Indeed, absolute and unlimited access to environmental information is not prescribed by the Aarhus Convention, given the range of grounds of refusal laid down in its article 4(3). Even Principle 10 of the Rio Declaration provides that individuals shall have 'appropriate access to information concerning the environment' (emphasis added), implying that there are matters for which access to information might be inappropriate, and that some restrictions may therefore be possible. In

105 See the Glyphosate appeal case (n 81) and the subsequent decision by the General Court Stichting Greenpeace Nederland and PAN Europe v Commission (n 99).

106 See Ludwig KRÄMER, 'Transnational access to environmental information' (2012) 1(1) Transnational Environmental Law 96 for a critical perspective on this.

107 See also Breyer (n 5o). Moreover, in ClientEarth (n 39), the Grand Chamber of the CJEU strengthened the already principled reasoning laid down in Saint-Gobain (n 32 ). 
this light, Principle 10 was less ambitiously formulated than article 42 of the Charter. ${ }^{108}$ At the same time-and remarkably—-the Aarhus Regulation does not refer to article 42 of the Charter. Reference is, however, made to article 37 of the Charter, which provides that a high level of environmental protection and the improvement of the quality of the environment must be integrated into the policies of the Union and ensured in accordance with the principle of sustainable development'.

Article 42 of the Charter provides a general right of access to information in the EU. This complements article 1 of the TEU, which emphasises openness of decision-making, as well as article 15 of the TFEU concerning access to documents. The analysis of the judicial argumentation by the CJEU shows that these general provisions of EU law on openness and transparency provide an important basis for the Court to require the Commission to disclose environmental information. Furthermore, the importance of openness is captured in recital 2 of the Access to Information Regulation, stating that '[o] penness enables citizens to participate more closely in the decision-making process and guarantees that the administration enjoys greater legitimacy and is more effective and more accountable to the citizen in a democratic system. Openness contributes to strengthening the principles of democracy and respect for fundamental rights as laid down in Article 6 of the EU Treaty and in the Charter of Fundamental Rights of the European Union.' Hence, the legal conflicts discussed above in section 3 were decided by the CJEU predominantly by using the general access to information provisions laid down in primary EU law. ${ }^{109}$ Only with regard to Glyphosate and Bijenstichting, specific environmental law reasoning was provided for interpreting the term 'emissions into the environment'. By interpreting this term in a broader way than the Aarhus Implementation Guide suggests, the possibility of keeping information secret is even more restricted.

\subsection{The Width of Transparent Governance Provisions}

This sub-section reflects critically on the onus placed on the European Commission to provide transparency during its decision-making process. While a high level of transparency is required, this may mean extra efforts and costs for the administration. Ultimately, this may impact negatively on the

108 See Principle 10, quoted in section 2.2.

109 The judicial decision in ClientEarth (n 39) (impact assessments) mainly rested on the access to information provisions of the Access to Information Regulation. However, the fact that the requested information was to be seen as environmental information seems to have strengthened the argument against the general presumption (see para 112 of the judgment). 
effectiveness of governmental decision-making. It has already been observed in the literature that a 'middle way is needed' that tries to take into account the various legitimate interests related to confidentiality versus transparency. ${ }^{110}$ In line with this, a few observations will be made below, aimed at promoting further debate on how to reach a balanced approach between transparency and confidentiality, particularly in view of the need for effective governance. ${ }^{111}$

First, during early stages of the decision-making process, one may wonder what impact openness may have on the effectiveness and efficiency of this decision-making. While the conflicts in the cases discussed above emerged because of a shortcoming on the part of the Commission in enabling the right to information (the first pillar of the Aarhus Convention), the judicial reasoning refers several times to participation in decision-making by the public (the second pillar of the Aarhus Convention). ${ }^{112}$ Such participation would be virtually impossible if the persons who are eligible for participation do not have sufficient information. The right to participate in governmental decisionmaking was introduced in the Aarhus Convention so that procedural rights can contribute to the right of every person of present and future generations to live in an environment adequate to his or her health and well-being. ${ }^{113}$ Also, with regard to the Escazú Agreement, it is observed that access to timely and reliable information means that members of the public can 'participate meaningfully in decisions affecting their lives.'114

However, in Saint-Gobain the CJEU considered that the Commission is not required to reply to comments from the public after the disclosure of information and that, consequently, the deadlines for decision-making are not put under pressure. ${ }^{115}$ One may doubt, however, whether this is really the case, particularly if the person asking for information is not just an ordinary member of the public trying to protect his or her living environment, but an industry that

110 KRÄMER, 'Transnational access to environmental information' (n 1o6) 96.

111 For a discussion that focuses on confidentiality of commercial information vis-á-vis transparency for the public, see KORKEA-AHO and LEINO (n 81) 109 o.

112 See, for instance, ClientEarth (n 40) and Saint-Gobain (n 32).

113 In contrast to the Aarhus Convention, article 4(1) of the Escazú Agreement obliges the parties to guarantee 'the right of every person to live in a healthy environment and any other universally-recognized human right related to the present Agreement': see DE SILVA (n 4) 96.

114 UN Environment Programme, 'Latin American and Caribbean countries sign historic treaty giving environmental rights the same status as human rights' (UN Environment Programme, October 2, 2018)

$<$ https://www.unenvironment.org/news-and-stories/story/latin-american-and -caribbean-countries-sign-historic-treaty-giving>.

115 Saint-Gobain (n 32$)$ para 84. 
will be economically and legally affected by the decision. Moreover, article 41 of the Charter of Fundamental Rights of the EU may be relevant in this respect. Article 41 establishes specific administrative procedural rights in view of the right to good administration. These include the right of every person to be heard before any individual measure is carried out that would affect him or her adversely, as well as the right of right of every person to have access to his or her file, while respecting the legitimate interests of confidentiality and of professional and business secrecy. In view particularly of the right to be heard, an argument could be constructed that the Commission is not totally free from failing to respond to comments, particularly from those members of the public (including economic actors) that would be legally affected by the measure. ${ }^{116}$

Secondly, the Court seems to expect that more openness promotes public support for the decisions taken. For instance, it has asserted that 'more effective public participation in the decision-making process [increases] ..., on the part of the competent bodies, the accountability of decision-making and [contributes] ... to public awareness and support for the decisions taken.'117 It may, however, be asked what empirical evidence supports this doctrinal view, particularly since 'the public' is a very abstract term. And, as daily practice shows, it is evident that many different opinions may arise in circumstances where a government wants to take a decision in the environmental field. Gathering public support can, as a value, be discerned from enabling the public to scrutinize decisions taken by the competent authorities in environmental matters, for example to avoid factual mistakes being made. In this sense, expert ENGOs play a valuable role in controlling and commenting on the content of the decision-making by authorities, but this does not necessarily mean that they will support the (political) decision taken. ${ }^{118}$ In other words, instead of straightforwardly pursuing, without critical reflection, a doctrine that openness is always positive, it would be useful to consider in a more detailed and nuanced way what exactly the most appropriate procedural rules are for access to documents and participation in the course of developing a decision.

116 In this sense, it would be important to consider what participation procedure would be necessary to apply, not only in view of the perspective of good administration, but also in view of enabling the public to participate to decision-making in order to try to protect the environment.

117 Glyphosate appeal case (n 81) para 80 (emphasis added). This idea of increasing public support by providing procedural rights can also be read in the preamble to the Aarhus Convention.

118 However, one could also ask to what extent the often complex information in the field of the environment is understood correctly by the public: Elisabeth FISHER, 'Transparency and Administrative Law: A Critical Evaluation' (2010) 63(1) Current Legal Problems 314. 
Thirdly, the value of transparency must be considered in the light of the administrative costs associated with generating that transparency. This dimension is not referred to explicitly in the decision by the Grand Chamber in ClientEarth. ${ }^{119}$ Further, virtually no consideration has been given to the criterion provided in the preamble to the Access to Information Regulation that the 'effectiveness of the institutions' decision-making process' should be 'preserved.' ${ }^{20}$ Regarding the effectiveness of the decision-making processes, empirical research into the use, application, and effects of procedural rights would provide more insight as to what extent they contribute to better environmental protection and what this means for administrative processes. This cannot be examined solely from a traditional legal approach (ie by identifying the positive law) but should move to an empirical investigation that includes the problems and costs that authorities experience when having to fulfil the duty to respond to requests for information. ${ }^{21}$ However, this should not be restricted to a purely quantitative analysis, with, for instance, a heavy focus on costs, but costs should be balanced against the great value of openness. Legal scholarship can contribute to such normative discussions. ZAHARCHENKO and GOLDENMAN, for instance, provided interesting insights into the qualitative appreciation of the Aarhus Convention in countries in East Europe and Central Asia. ${ }^{122}$ Carrying out semi-structured interviews with civil servants and politicians, with members of civil society and with other actors, such as entrepreneurs, could provide meaningful insights into the costs and positive effects of applying environmental procedural rights. Such research can deliver more nuanced visions on the value of access to environmental information. Hence, next to identifying (and stimulating) the application of environmental procedural rights as codified in the law, environmental law scholars should not avoid reflection on the doctrinal underpinnings of the provisions on transparency, and their interpretation by the courts. Also, the practical consequences of the doctrine of openness and transparency should be critically reflected on. Cooperation with other intra-law disciplines (such as with administrative and constitutionalspecialists)and otherrelevantdisciplines,suchaspoliticalscience, seems to be needed in order to gain a more thorough insight into the implications

\footnotetext{
119 ClientEarth (n 39).

120 Access to Information Regulation, recital 6. That part of the recital was not referred to in ClientEarth (n 39) para 84. Explicit mention was, however, made of the first sentence of recital 6 , specifically that 'wider access should be granted to documents in cases where the EU institutions are acting in their legislative capacity'.

121 The observation by FISHER ( $\mathrm{n} 118$ ) 314 is illustrative: 'transparency may be a truism in regard to public administration, its operation is profoundly complex.'

122 ZAHARCHENKO and GOLDENMAN (n 6).
} 
and application of environmental democracy as laid down in the Aarhus Convention. In this respect, attention should not only be given to democratic values, but also to other values embedded in the law, such as 'preserving the effectiveness of the institutions' decision-making process' mentioned in the preamble to the Access to Information Regulation. ${ }^{123}$

\section{Conclusion and an Outlook on Future Comparative Research}

This article has provided some insights into how the CJEU enforces the right of access to environmental information. The CJEU, by annulling decisions of the European Commission that refused to disclose environmental information, has clearly contributed to strengthening 'environmental democracy' in the EU. Its adjudication is based on general values related to openness and transparency of decision-making as enshrined in primary EU law. Future case law may also show whether the specific 'Aarhus' provisions on access to environmental information will further strengthen the already-wide onus put on the EU administration to provide transparency. In this respect, according to the CJEU, a wide interpretation needs to be given of what is to be understood by 'emissions into the environment'. Nonetheless, further legal conflicts on and refusals of disclosure of environmental information may emerge, particularly related to the grounds provided by the regulatory framework to justify confidentiality, such as the protection of international relations ${ }^{124}$ or the prevention of adverse consequences for the environment. ${ }^{125}$

While the CJEU, thus far, has clearly taken a firm stance on promoting transparency, ${ }^{126}$ a discussion is equally needed on what this broad openness means for administrative law practice. This discussion needs to focus on how the legal framework enables the administration, including the EU Commission, to balance between, on the one hand, transparent governance, and, on the other hand, preserving the efficiency and effectiveness of its decision-making. In order to gain more insight into how to apply transparency in environmental matters, it would be valuable to focus not only at EU level, but also to examine the experiences and perceived values on transparency at Member State level. While Sweden and Finland supported ClientEarth

\footnotetext{
123 Access to Information Regulation, recital 6.

124 Access to Information Regulation, article 4(1) and Aarhus Convention, article 4(b).

125 Aarhus Regulation, article 6(2) and Aarhus Convention, article 4(h).

126 Although disclosure is not always required, see for instance C-524/o9 Ville de Lyon v Caisse des dépôts et consignations [2010] ECLI:EU:C:2010:822.
} 
in a legal procedure fighting against refusal of disclosure of information by the European Commission, ${ }^{127}$ the case law discussed in this article shows that Germany has more than once resisted disclosure of information. ${ }^{128}$ This aligns with the observation of BÜNGER and SCHOMERUS that resentment in Germany concerning the provision of broad access to information is due to a fear of public interest environmental activism. ${ }^{129}$ This apparent reluctance around transparency indicates that, across jurisdictions within the European Union, the ideas and application in practice regarding access to environmental information may differ greatly. Differences may also become evident when engaging in comparative research on the right of access to environmental information by examining legal practice in countries across the world. It would be interesting and useful to investigate how the widely acknowledged value of providing appropriate access to environmental information can be really effectuated in legal practice, and what similarities and differences can be identified in the legitimate exercise of this right. ${ }^{130}$

Furthermore, the analysis of case law above shows that access to environmental information cannot be seen in isolation by focussing solely on the environmental law framework, at least in the case of the EU. The judicial enforcement of access to environmental information is rooted in codified core values of openness and transparency in EU primary law. Comparative studies with judicial developments on access to environmental information in other jurisdictions should of course take account of the different legal traditions and cultures with regard to transparency. Furthermore, administrative capacity and financial capacity may be relevant when discussing the governmental duty to disclose information upon request. ${ }^{131}$ If the right to environmental information is to be widely exercised by the public, as an essential aspect of a lively

\footnotetext{
127 ClientEarth (n 39).

128 Examples are Saint-Gobain (n 32), Flachglas Torgau (n 57), Deutsche Umwelthilfe (n 57) and the Glyphosate appeal case (n 81).

129 Dirk BÜNGER and Thomas SCHOMERUS, 'Private Bodies as Public Authorities under International, European, English and German Environmental Information Laws' (2011) 8(1) Journal for Environmental and Planning Law 8o.

130 Relevant work has already been done by the World Resources Institute by developing an environmental democracy index, presented in an archived website created in 2015 (n 16). This index encompasses 70 countries and is based on 75 legal indicators, including the main national freedom-of-information law, see <http://environmentaldemocracyindex .org/about/background_and_methodology>.

131 In the technical note to the Environmental Democracy Index, it is observed that 'state capacity', next to willingness to adopt reforms, 'is undoubtedly critical to achieve the intended impact', see Jesse WORKER and Lalanath DE SILVA, 'The Environmental Democracy Index. Technical note.' World Resource Institute, Working Paper June 2015, 3.
} 
environmental democracy, governments must respond to such requests in an adequate way. This includes a duty to expend effort on collecting and disseminating information. They must also make careful decisions about whether the information can in fact be provided. This may be an issue if the disclosure of environmental information may affect the economic interests of third parties. It would be useful to try to identify the specific reasons that are used to permit the non-disclosure of environmental information, based on the examination of selected core cases and other decision-making processes, and then to reflect on whether this confidentiality should be discouraged in view of promoting the important concept of environmental democracy. Whether the balance will be tilted towards disclosure instead of confidentiality may turn out differently in jurisdictions across the world. Further examination will teach us how the right to environmental information will mature in practice, and to what extent courts in other jurisdictions must step in as guardians of environmental democracy, in the way that the cJEU clearly has done. 